\title{
Sosialisasi Kemukjizatan Al Qur'an Terhadap Komunitas Pendengar Radio Baiturrahman Aceh Melalui Program Interaktif Al Qur'an dan Sains
}

\author{
${ }^{1}$ Andri Nirwana, Ainal Fitri, Rahmadon, Fitri Meliya sari, Fahmi Arfan, Zahari \\ Universitas Serambi Mekkah Banda Aceh \\ 1andri.nirwana@serambimekkah.ac.id
}

\begin{abstract}
This dedication article aims to socialize the miracles of the Qur'an in the scientific field. Based on our observation that the public does not know what scientific content the Qur'an has. The findings from the results of this dedication are people with an educational background who have a good understanding of the delivery of material content, it is different from ordinary people, their impression of this program is good and requires a slow delivery strategy so that the message conveyed can be understood. This activity provides many benefits to the Radio community listeners loyal to Baiturrahman in increasing insight, literacy in understanding the miracles of the Qur'an.
\end{abstract}

Keywords: Miracle; Scientific; Radio; Al Qur'an

\begin{abstract}
Abstrak
Artikel pengabdian ini bertujuan untuk mensosialisasikan kemukjizatan Al Qur'an di bidang saintifik ilmiah yang berdasarkan observasi kami bahwa masyarakat tidak mengetahui apa kandungan ilmiah yang dimiliki oleh Al Qur'an. Penemuan dari hasil pengabdian ini adalah masyarakat dengan latar belakang pendidikan memiliki pemahaman yang baik atas penyampaian isi materi, berbeda hal nya dengan masyarakat awam, Kesan mereka terhadap program ini bagus dan membutuhkan strategi penyampaian secara lambat agar pesan yang disampaikan dapat dimengerti dan dipahami. Kegiatan ini memberikan banyak manfaat terhadap masyarakat awam pendengar radio setia Baiturrahman dalam meningkatkan wawasan, literasi dalam pemahaman kemukjizatan AI Qur'an.
\end{abstract}

Kata Kunci: Mukjizat, Sains, IImiah, Radio, Al Qur'an

\section{Pendahuluan}

Mukjizat mempunyai kandungan sebuah kekuatan untuk melemahkan lawan dan lawan takjub akan kekutan tersebut. Sesuatu yang mampu melemahkan lawannya, maka dapat dikatakan dia mempunyai mukjizat. Al Qur'an mempunyai beberapa mukjizat, diantaranya Susunan Redaksi ayat yang mampu melemahkan para penyair sastra Arab di masa Jahiliyah. Tidak ada seorang pun yang mampu menandingi redaksi dan kandungan hikmah yang dalam dari Al Qur'an. Redaksi ayat Al Qur'an mampu meluluhkan hati manusia yang cerdas untuk memeluk Islam. Dalam Sejarah tertuliskan Umar bin Khattab Masuk Islam akibat takjub terhadap redaksi ayat al Qur'an surat Toha. Redaksi Al Quran menggunakan bahasa Arab mempunyai keistimewaan, seperti yang disebutkan dalam Al Qur'an surat As Syu'ara ayat 195 yang artinya Al Qur'an itu turun dengan bahasa Arab yang Mubin (jelas). Ibnu Faris seorang ulama bahasa menyebutkan bahwa Allah memilih bahasa Arab karena bahasa Arab adalah bahasa yang tertinggi tingkatan dan levelnya dibandingkan dengan bahasa lain nya di dunia. Alasan lain nya adalah bahasa Arab adalah bahasa yang tertua dan sangat terjaga. Semakin tua sebuah bahasa maka semakin sempurna gramatikal dan simbol-simbol maknanya. Imam As Suyuti memuji kekayaan ilmu linguistik dalam bahasa arab, misalnya untuk penyebutan satu benda, bahasa Arab 
memiliki beberapa istilah untuk satu benda, sedangkan bahasa bahasa lain di dunia tidak mempunyai keistimewaan demikian. ${ }^{1}$

Mukjizat Al Qur'an yang lain adalah dalam bidang hukum. Al Quran telah memberikan penawaran solusi terhadap tindakan pelanggar hukum. Terbukti berhasil diterapkan pada masa awal awal khalifah, sehingga Islam menyebar ke seluruh penjuru dunia. Inilah bukti bahwa AI Qur'an dalam bidang hukum mampu melemahkan hukum hukum manusia.

Mukjizat al Qur'an yang terakhir adalah Al Qur'an menyinggung pencerahan tentang sains. Diawali dengan perintah lqra untuk memahami sinyal-sinyal alam, fenomena terbaru dan prediksi kejadian ke depan. Mukjizat ilmiah ini mampu melemahkan pikiran-pikiran manusia sehingga mereka mendapatkan hidayah untuk memeluk Islam. Banyak contoh manusia cendikia akhir zaman yang memeluk Islam akibat mendapatkan hidayah dari Riset berkaitan dengan ayat al Qur'an. Ayat al Quran yang menginformasikan tentang fenomena alam berjumlah lebih dari 750 ayat. $^{2}$

Kegiatan pengabdian ini memilih beberapa ayat sains sebagai materi pembahasan dan disiarkan secara langsung dan dibuka layanan interaktif untuk melihat Respon pendengar radio Baiturrahman. Diantara Materi yang kami sampaikan yaitu Manusia yang mampu menembus hukum ruang dan waktu dalam al Qur'an, Fenomena Ayam berkokok, Fenomena Api di dasar laut, Fenomena prediksi kekalahan Kerajaan Romawi, Fenomena luar angkasa, Fenomena Jasad Firaun yang diselamatkan dan fenomena Zikir nya Tumbuhan dan hewan.

\section{Lokasi}

Kegiatan ini bertempat di Studio Radio Baiturrahman yang beralamat di Merduati, kecamatan Kuta Raja, Kota Banda Aceh, di frekuensi 98,5 FM.

\section{Sasaran Kegiatan Pengabdian}

Sasaran Kegiatan ini adalah para pendengar radio Baiturrahman di Kota Sigli, Kota Pulau Sabang, Pulau Aceh, Kabupaten Aceh Besar dan warga kota Banda Aceh. Profesi bermacam-macam seperti Pedagang, Petani, Pegawai pemerintah, Wiraswasta dan lain lain.

\section{Tahapan Persiapan}

Persiapan yang kami lakukan adalah dengan membangun kerja sama dengan pihak radio baiturrahman dalam bentuk MOA, mengumpulkan materi penyampaian, Pengukuran waktu penyampaian selama satu jam, waktu penyiaran yaitu pukul 9 sampai pukul 10.00, setiap hari jumat pagi.

Materi pembahasan disesuaikan selama satu Semester di awal Bulan, sejak September 2016 sampai dengan Februari 2017 dengan Pembahasan yaitu Manusia yang mampu menembus hukum ruang dan waktu dalam al Qur'an, Fenomena Ayam berkokok, Fenomena Api di dasar laut, Fenomena prediksi kekalahan Kerajaan Romawi, Fenomena luar angkasa, Fenomena Jasad Firaun yang diselamatkan dan fenomena Zikir nya Tumbuhan dan hewan.

\footnotetext{
${ }^{1}$ Andri Nirwana, Ulumul Qur'an dan Ulumul Hadis, (Banda Aceh, Sear Fiqh, 2015), hlm. 93

${ }^{2}$ Andri Nirwana, Tafsir ayat ayat Sains, (Banda Aceh, Searfiqh, 2016), hlm 53
} 


\section{Tahap Pelaksanaan}

Pelaksanaan kegiatan pengabdian Masyarakat berjalan sukses dan lancar sesuai dengan perencanaan. Pemateri menyampaikan materi dengan baik dan lancar dan banyak respon dari para pendengar yang menelpon langsung ke Radio Baiturrahman.

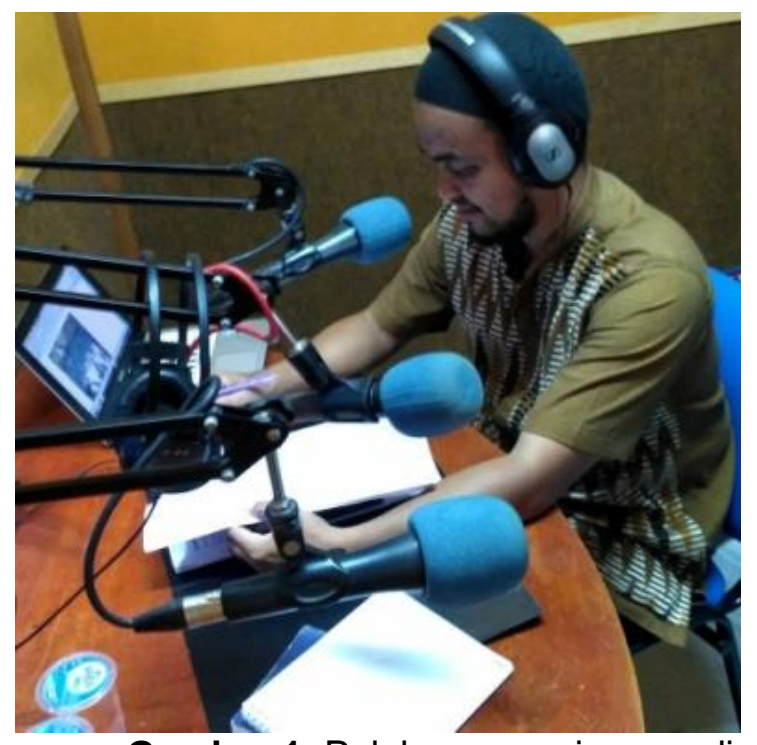

Gambar 1: Pelaksanaan siaran radio

Adapun Jadwal program yang telah disusun sebagai berikut:

Tabel 1: Jadwal Program

\begin{tabular}{|c|c|c|c|c|}
\hline Materi & Pembahas & Tanggal & Hari/ Waktu & $\begin{array}{c}\text { Operator } \\
\text { Radio }\end{array}$ \\
\hline $\begin{array}{l}\text { Manusia } \\
\text { Menembus } \\
\text { ruang dan waktu }\end{array}$ & $\begin{array}{lr}\text { Dr. } & \text { Andri } \\
\text { Nirwana. } & \text { AN, } \\
\text { S.TH, M.Ag } & \\
\end{array}$ & $\begin{array}{l}9 \text { september } \\
2016\end{array}$ & $\begin{array}{l}\text { Jumat, 09.00- } \\
10.00 \text { Pagi }\end{array}$ & Masyudi \\
\hline $\begin{array}{l}\text { Rahasia mata } \\
\text { ayam dan kokok } \\
\text { nya }\end{array}$ & $\begin{array}{l}\text { Ainal } \\
\text { M.I.Kom }\end{array}$ & 7 oktober 2016 & $\begin{array}{l}\text { Jumat, 09.00- } \\
10.00 \text { Pagi }\end{array}$ & Nasruddin \\
\hline $\begin{array}{l}\text { Fenomena Api } \\
\text { di dasar Laut }\end{array}$ & $\begin{array}{l}\text { Rahmadon, } \\
\text { M.Ed, Ph.D }\end{array}$ & $\begin{array}{ll}4 & \text { Nopember } \\
2015 & \end{array}$ & $\begin{array}{l}\text { Jumat, 09.00- } \\
10.00 \text { Pagi }\end{array}$ & Masyudi \\
\hline $\begin{array}{l}\text { Prediksi } \\
\text { kekalahan } \\
\text { Kerajaan Super } \\
\text { power Romawi } \\
\text { dalam Al Qur'an }\end{array}$ & $\begin{array}{l}\text { Fitri Meliya Sari, } \\
\text { M.I. Kom }\end{array}$ & $\begin{array}{ll}2 & \text { Desember } \\
2016 & \end{array}$ & $\begin{array}{l}\text { Jumat, 09.00- } \\
10.00 \text { Pagi }\end{array}$ & Nasruddin \\
\hline $\begin{array}{l}\text { Fenomena luar } \\
\text { angkasa dan } \\
\text { lapisan Langit }\end{array}$ & $\begin{array}{l}\text { Fahmi Arfan, } \\
\text { M.Pd }\end{array}$ & 6 Jan 2017 & $\begin{array}{l}\text { Jumat, 09.00- } \\
10.00 \text { Pagi }\end{array}$ & Masyudi \\
\hline $\begin{array}{lr}\text { Mayat } & \text { Firaun } \\
\text { yang } & \text { tidak } \\
\text { busuk } & \\
\end{array}$ & $\begin{array}{l}\text { Dr. Zahari, } \\
\text { M.Kom.I }\end{array}$ & 3 Februari 2017 & $\begin{array}{l}\text { Jumat, 09.00- } \\
10.00 \text { Pagi }\end{array}$ & Nasruddin \\
\hline
\end{tabular}




\section{Model Pengabdian}

Pengabdian ini menggunakan Metode Ceramah dan Tanya Jawab, hanya menggunakan kekuatan Audio atau pendengaran saja. ${ }^{3}$ Karena hakikat tujuan nya adalah untuk memberikan wawasan bahwa AI Qur'an ini mempunyai kemukjizatan dari sisi ilmu pengetahuan dan Tekhnologi, yang hanya dipahami oleh kalangan cendikiawan saja, bukan untuk masyarakat awam.

\section{Analisis Keberhasilan}

Ukuran capaian keberhasilan program pengabdian masyarakat ini ditentukan oleh banyak nya para penelpon yang memberikan pertanyaan, apresiasi dan Tanggapan terhadap program ini. Hampir setiap sesi program interaktif al qur'an sains ini mendapatkan bunyi telepon yang bertubi tubi dis etiap sesi nya.

\section{Temuan}

Hasil dari kegiatan ini, kami menemukan bahwa banyak masyarakat pendengar Radio kurang memahami wawasan pengetahuan al Qur'an, dikarenakan mereka lebih senang kepada hal hal hiburan. Ketika program ini hadir, maka mereka seolah-olah tercerahkan dan menambah wawasan baru dalam religiustik.

\section{Rekomendasi}

Kami merekomendasikan kepada Radio radio lain untuk gemar memberikan pengetahuan Al Qur'an terhadap para pendengar Radio. Media radio sangat efektif karena para pendengar juga bisa melakukan kegiatan lain nya, sambilan mendengar radio.

\section{Kesimpulan}

Kegiatan pengabdian kepada masyarakat Program studi Komunikasi Penyiaran Islam universitas Serambi Mekkah mendapatkan beberapa kesimpulan seperti adanya Respon dan reaksi positif dari Direktur Radio, para penyiar, para pendengar dan masyarakat awam lain nya. Kegiatan ini memberikan manfaat kepada masyarakat yaitu memahami peran AI Qur'an terhadap sains dan tekhnologi, sehingga fungsinya sebagai hudal linnas dalam ilmu tekhnologi juga berperan.

\section{Daftar Pustaka}

Nirwana, Andri (2015), Ulumul Qur'an dan Ulumul Hadis, Banda Aceh, Searfiqh

------, (2016), Tafsir ayat ayat Sains, Banda Aceh, Searfiqh

Persada

$$
\text { (2019), Tafsir Tematik Al Qur'an, Banyumas Jawa Tengah, Pena }
$$

Muttaqin, Khairul dkk,(2019), Metode cepat membaca Al Qur'an di Yayasan

Miftahul Ulum Kecamatan Lenteng Kabupaten Sumenep dalam Jurnal

Perdikan: (Journal of Community engagement), Vol 1 Nomor 1

\footnotetext{
${ }^{3}$ Khairul Muttaqin dkk, Metode cepat membaca Al Qur'an di Yayasan Miftahul Ulum Kecamatan Lenteng Kabupaten Sumenep dalam Jurnal Perdikan: (Journal of Community engagement, Vol 1 Nomor 1 tahun 2019, hlm 17
} 